\title{
EVALUATION OF RURAL LANDSCAPE FUNCTIONS BASED ON DOMESTIC CASE STUDY
}

\author{
FilePNÉ KovÁCs, K.* - NAGY, G.G. - KolLÁNYI, L. \\ Corvinus University of Budapest, Dept. of Landscape Planning and Regional Development \\ 1118 Budapest, Villányi út 29-43., Hungary \\ (phone: +36-1-482-6281; fax: +36-1-482-6338) \\ *Corresponding author \\ e-mail: krisztina.kovacs@uni-corvinus.hu \\ (Received $18^{\text {th }}$ October 2011; accepted $5^{\text {th }}$ December 2011)
}

\begin{abstract}
Nowadays a new research field is the application of the so called landscape indicators which serve the description and evaluation of landscapes. In this study we analyze landscape functions and ecosystem services in rural landscapes. We summarize most of the services/functions of the landscapes and analyze its balanced functioning in the case of micro-region of Csorna situated in Western-Hungary. The micro-region is comprised of two major landscape units. One is the Hanság, Tóköz which still preserved the values of the former vast marshland. The analyzed indices show that the population can not really enjoy the benefits of natural values; the recreational and cultural-educational functions are inadequate in spite of the high rate of protected areas. The ratio of cultivated areas is very high Looking at the landscape aesthetics functions the protected areas are of high value but in the cultivated areas especially plough fields the planting of elements of mosaic like and the traditional landscape such as vegetation along canals, forest belts, trees and greater areas of pastures should be enhanced. The second part of the micro-regions is Rábaköz which can be characterized by high intensity of cultivation. Here we revealed that the habitat (and regulation) and information (aesthetics, recreation, education) services are inadequate.
\end{abstract}

Keywords: carrier function, ecosystem services, micro-region of Csorna, multifunctionality, sustainable development

\section{Introduction}

Because of the increased pressure of population growth since the 1950s there is an increased need for the natural resources (e.g. food, water, wooden, fuel). These unfavourable processes loaded the ecosystems of the earth on an unprecedented scale. The most important driving factors are the conversion of habitats, climate change, biological invasion, overuse and pollution (Török, 2009). Evaluating the effects of the unfavourable processes more and more experts and civil recognized that the human welfare depends on the services and goods of nature summarized in ecosystem services (MEA, 2005) or natural capital (Costanza et al., 1997; de Groot et al., 2002).

The existence of the society is essentially based on landscapes, so the analysis of the ecosystem services shall cover the entirety of the services of natural and semi-natural systems of these landscapes. This logic leads us to the concept of landscape functions, which in case of rural landscapes with extensive, natural or semi-natural land cover almost entirely is identical to ecosystem services. The primary role of these tools is to support and substantiate decision making having impact on ecosystem functioning or their management, and therefore should be deeply considered by both local and global political decision makers. There are a number of options to group assets offered by nature, very often the next being an advanced version of the previous one, thus so much similar to one other (de Groot, 1992, 2006; Costanza et al., 1997; MEA, 2005). In case 
of three groups of services there is a consensus of opinion: provisioning services (food, timber, etc.), regulating services (climate control, water purification, etc.) and information services (recreation, education, etc.).

These services and landscape functions are provided by the biological and landscape diversity so it is inevitable to maintain the biodiversity and to turn back the unfavourable processes. It is particularly true for the rural landscapes which are the most important food production places of the humankind, which next to the production function fulfils important social/cultural and landscape/nature protection functions as well (EEC, 1992). Several studies reveal the fact that those landscapes will be competitive in the future which maintain such landscape management which is based on the natural resources following the concept of precaution and accept that the society is organic part of the nature (Glatz, 2010). So it is inevitable to relate the concept of competitiveness in case of rural areas with the ecosystem services/landscape functions of the landscape breaking with the traditional interpretation of the nowadays so fashionable concept of competitiveness. The nowadays so fashionable concept is mostly related to economic aspects incidentally considering social issues and environmental aspects. In case of rural areas we consider the competitiveness as the ability of rural areas to preserve their population, so it is important to fulfil the needs of society as well. But we can not rely on the economic issues and conditions. We highlight the balance of economic, social and environmental needs and aspects which spatially reflect in the land use system and land use functions of the landscapes. The landscape conditions especially the land use forms play an important role in maintaining proper life quality of rural population so in the competitiveness of rural settlements.

There have been used indicators for the description of regions and settlements for a long time. So, nowadays we can reach indicators quiet easily to present the economic and social conditions (Central Statistic Office, TEIR, etc.). Another popular field of indicators is the environmental monitoring. The growing environmental concern led to the application of wide range of environmental indices. Rather new research field is the application of the so called landscape indices which serve the description and evaluation of the landscapes. There is no accepted practice for developing landscape indicators. The majority of the indicators come from agri-environmental researches as the management, ecologic state or "state of health" of landscapes is mostly determined by agricultural practices. It is important to find simple, easily available indicators. There is a wide range of data sources available: former plans, study in the field, maps (maps with the present state - CORINE Land Cover, tourist and historic maps, etc.), data basis (Central Hungarian Statistic Office, TEIR, database of national monuments, database of landscape values - TÉKA, nature and environmental protection databases), guide books, monographs, Internet, etc.

But what are those indicators which bear importance and significance also for rural development, which give information how we could use the landscape conditions in a more rational and sustainable way enhancing life quality and improve income of rural population and in its entirety to enhance preservation ability of population of rural regions. In our approach a balanced system of the existing landscape functions (multifuncionality) serve in a better way the preservation ability of population of rural regions.

The entirety of landscape conditions offers wide range of possibilities of different activities for the public (Konkoly-Gyúró, 2003). It is an important aspect how can be served or fulfilled the growing demand and diverse expectations of the society 
meanwhile maintaining the environmental quality which is covered by the aspect of multifunctionality of landscape management. First of all the demand of multifunctionality was formed in case of agriculture (CAP reforms). The primary sector fulfils a main function - production and related joint productions including tangible and non-tangible goods and a mix of private and public goods (externalities).

The landscape is regarded a physical spatial unit that fulfil several purposes (several functions) for the society. In the 1990s increased attention was paid on the multifunctional character of the landscape, mostly because many environmental problems of the countryside were considered related to the segregation of functions and disappearance of other functions than production from the rural areas. In the landscape production is just one function among many others (Vejre et al., 2007).

In this paper we analyze some ecosystem services/landscape functions of landscapes and look for simple available indicators for description of landscape functions to highlight the imbalances. We apply the concept for the micro-region of Csorna situated in Western-Hungary (Fig. 1). Because of the differing landscape conditions we divided the administrative spatial unit into two groups: settlements of Hanság, Tóköz and Rábaköz.

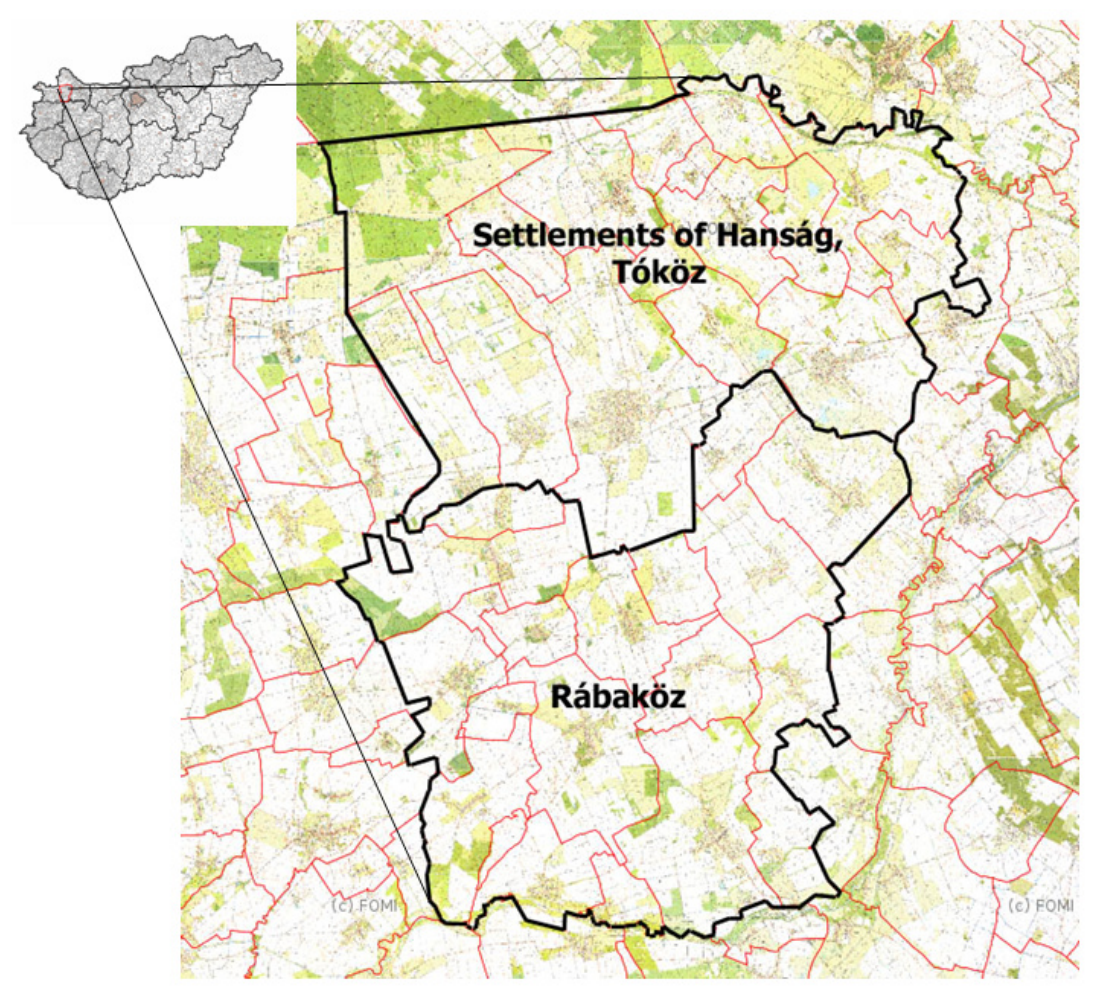

Figure 1. Micro-region of Csorna with the two groups of settlements

\section{Materials and methods}

In this paper we follow the classification system of de Groot (2006) emphasizing the services and functions of the landscape for the society. Regulation functions cover all the ecological processes and life support systems (geochemical cycles, biospheric processes) which are inevitable in the maintenance of "healthy ecosystems" at different scale levels. Habitat functions relate to the spatial conditions needed to maintain biotic (and genetic) diversity and evolutionary processes. These services can be described in 
terms of carrying capacity and spatial needs (minimum critical ecosystem size) of the natural ecosystems which provide them. Production functions mean many resources of the nature for human use (food, raw material-fibre, timber, etc.). Information functions cover all the services related to recreation, reflection, cognitive development and aesthetic experience. Finally de Groot distinguishes carrier functions which include cultivation, habitation and transportation. This group of services includes all the human activities which converse the original ecosystem. Of course there are overlaps and interactions between the different functions, for example the carrier function offer other goods such as cultivated landscape maintain regulation services as well and have aesthetic qualities, etc. (de Groot, 2006). Applying the subdivision of de Groot we summarized the functions and landscape architecture requirements of the landscape functions in Table 1.

Table 1. Landscape functions and ecologic services and aspects of landscape architecture (sources: Leader European Observatory (2001), Ghimessy (1984), de Groot (2006))

\begin{tabular}{|c|c|c|c|}
\hline $\begin{array}{l}\text { Main groups } \\
\text { of functions }\end{array}$ & Landscape functions & Examples & $\begin{array}{c}\text { Requirements of landscape } \\
\text { architecture }\end{array}$ \\
\hline \multirow{7}{*}{$\begin{array}{l}\text { Carrier } \\
\text { functions }\end{array}$} & $\begin{array}{l}\text { Agricultural } \\
\text { cultivation }\end{array}$ & $\begin{array}{l}\text { - Permanent spatial } \\
\text { production elements } \\
\text { - Agricultural areas }\end{array}$ & $\begin{array}{l}\text { Agricultural production fitting } \\
\text { landscape conditions (relief, } \\
\text { soil, water resources, etc.) }\end{array}$ \\
\hline & Forestry & - Forests & $\begin{array}{l}\text { - Forests containing domestic } \\
\text { species characteristic for the } \\
\text { landscape }\end{array}$ \\
\hline & $\begin{array}{l}\text { Energy- } \\
\text { conversion }\end{array}$ & $\begin{array}{l}\text { - Areas for water } \\
\text { management and water } \\
\text { power plants } \\
\text { - Wind energy parks, etc. }\end{array}$ & - Favouring renewable resources \\
\hline & Mining & $\begin{array}{l}\text { - Not renewable spatial } \\
\text { production elements } \\
\text { - Mining } \\
\text { - Industrial sites }\end{array}$ & $\begin{array}{l}\text { - Rehabilitation of devastated } \\
\text { surfaces }\end{array}$ \\
\hline & $\begin{array}{l}\text { Connection- } \\
\text { Transportation }\end{array}$ & $\begin{array}{l}\text { - Areas serving roads, } \\
\text { railways, water-, gas, } \\
\text { electric lines }\end{array}$ & $\begin{array}{l}\text { - Minimizing negative effects of } \\
\text { infrastructure } \\
\text { - Accessibility of markets } \\
\text { - Efficient infrastructural } \\
\text { network for economic activities }\end{array}$ \\
\hline & $\begin{array}{l}\text { Residential } \\
\text { function }\end{array}$ & $\begin{array}{l}\text { - Settlements and green } \\
\text { spaces }\end{array}$ & $\begin{array}{l}\text { - Satisfying social need and } \\
\text { preserving architectural } \\
\text { traditions and green spaces } \\
\text { - Ensuring quality of life } \\
\text { - Integration of settlers } \\
\text { - Planning serving the needs of } \\
\text { socialization and integration: } \\
\text { community places, sport } \\
\text { centres }\end{array}$ \\
\hline & Waste disposal & & $\begin{array}{l}\text { - Recultivation, re-use of } \\
\text { abandoned land fills }\end{array}$ \\
\hline
\end{tabular}


Table 1. cont.

\begin{tabular}{|c|c|c|c|}
\hline $\begin{array}{l}\text { Main groups } \\
\text { of functions }\end{array}$ & Landscape functions & Examples & $\begin{array}{c}\text { Requirements of landscape } \\
\text { architecture }\end{array}$ \\
\hline $\begin{array}{l}\text { Regulation } \\
\text { function }\end{array}$ & $\begin{array}{ll}- & \text { Preservation of } \\
& \text { biodiversity } \\
- & \text { Gas regulation } \\
- & \text { Climate regulation } \\
- & \text { Water regulation } \\
- & \text { Water supply } \\
- & \text { Soil retention } \\
- & \text { Soil formation } \\
- & \text { Waste treatment }\end{array}$ & $\begin{aligned} & \text { - } \text { Areas under nature } \\
& \text { protection } \\
& \text { - Areas for water } \\
& \text { protection } \\
& \text { - Protection zones of } \\
& \text { industrial areas } \\
& \text { - Protection zones of } \\
& \text { residential areas }\end{aligned}$ & $\begin{array}{l}\text { - Spatial planning serving the } \\
\text { protection of biodiversity: } \\
\text { protection of biotope mosaic } \\
\text { like landscapes, ecologic } \\
\text { corridors }\end{array}$ \\
\hline \multirow{2}{*}{$\begin{array}{l}\text { Habitat } \\
\text { function }\end{array}$} & Refugium function & $\begin{array}{l}\text { - Areas under nature } \\
\text { protection }\end{array}$ & $\begin{array}{l}\text { Maintenance of biotopes, } \\
\text { mosaic like landscapes, } \\
\text { ecologic corridors }\end{array}$ \\
\hline & Nursery function & $\begin{array}{l}\text { - Habitats of agricultural } \\
\text { fields: forest belts among } \\
\text { agricultural fields etc. }\end{array}$ & $\begin{array}{l}\text { - Environmental and nature- } \\
\text { friendly agriculture }\end{array}$ \\
\hline \multirow{4}{*}{$\begin{array}{l}\text { Information } \\
\text { function }\end{array}$} & $\begin{array}{l}\text { Cultural and } \\
\text { artistic function }\end{array}$ & $\begin{array}{l}\text { - Areas for national } \\
\text { monument preservation } \\
\text { - Archaeological sites } \\
\text { - Unique landscape values } \\
\text { - Historic landscapes }\end{array}$ & $\begin{array}{l}\text { - Listing and preservation of } \\
\text { values of regional identity } \\
\text { - Community places presenting } \\
\text { local heritage }\end{array}$ \\
\hline & $\begin{array}{l}\text { Recreational function } \\
-\quad \text { Satisfying the needs } \\
\text { of urban society: } \\
\text { leisure, recreation, } \\
\text { sports } \\
\text { - Harmonizing the } \\
\text { needs of locals and } \\
\text { tourists }\end{array}$ & $\begin{array}{l}\text { - Thematic parks } \\
\text { - Nature parks } \\
\text { - Park forests }\end{array}$ & $\begin{array}{l}\text { - Changing rural spaces for } \\
\text { spaces of learning and } \\
\text { discovery: thematic routes, } \\
\text { study trails, visitor centre }\end{array}$ \\
\hline & $\begin{array}{l}\text { Scientific and } \\
\text { educational function }\end{array}$ & $\begin{array}{l}\text { - Thematic parks } \\
\text { - Nature parks } \\
\text { - Study trails } \\
\text { - Unique landscape values }\end{array}$ & $\begin{array}{l}\text { - Listing and preservation of } \\
\text { landscape values }\end{array}$ \\
\hline & Aesthetic information & $\begin{array}{l}\text { - Attractive landscape } \\
\text { features }\end{array}$ & $\begin{array}{l}\text { - Preservation of the beauty and } \\
\text { aesthetic value of the } \\
\text { landscape } \\
\text { - Decreasing the monotony of } \\
\text { agricultural fields (forest belts) }\end{array}$ \\
\hline \multirow{5}{*}{$\begin{array}{l}\text { Production } \\
\text { function }\end{array}$} & $\begin{array}{l}\text { Food } \\
\text { (hunting, gathering of } \\
\text { fish, game, fruits.) }\end{array}$ & $\begin{array}{l}\text { - Small scale } \\
\text { subsistence farming } \\
\text { - Goods of nature } \\
\text { protection areas }\end{array}$ & $\begin{array}{l}\text { - Environmental requirements } \\
\text { - Environmental education }\end{array}$ \\
\hline & $\begin{array}{l}\text { Raw materials } \\
-\quad \text { Building and } \\
\text { manufacturing } \\
- \text { Fuel and energy } \\
-\quad \text { Fodder and fertilizer }\end{array}$ & & $\begin{array}{l}\text { - Use for unique and local } \\
\text { products }\end{array}$ \\
\hline & Genetic resources & & $\begin{array}{l}\text { - Use of diverse, endemic plant } \\
\text { material }\end{array}$ \\
\hline & Medicinal resources & & \\
\hline & $\begin{array}{l}\text { Ornamental } \\
\text { resources }\end{array}$ & & $\begin{array}{l}\text { - Resources for fashion, } \\
\text { jewellery, handicraft }\end{array}$ \\
\hline
\end{tabular}


Analyzing the range of economic, social and landscape indices there are countless possible indicators. We have strived to find simple, easily available indicators for all landscape functions giving meaningful interpretation of the services of landscape. In some cases we could rely descriptive indicators and experiences of the on the spot survey. In rural development mostly we can influence the carrier and information functions and because of sustainability and its additional services we consider the habitat function.

We analyzed the chosen functions through the following indicators:

- Habitat function (share of protected areas)

- Information functions

- Cultural function including education (unique landscape values, study trails, exhibitions)

- Recreational function (capacity of rural tourism and recreational possibilities).

- Aesthetic information (attractive landscape features, characteristic landscape elements)

- Carrier function (cultivation - share of cultivated areas).

We have analyzed the above mentioned functions and aspects in the case of microregion of Csorna situated in the Small-Plain between the great centers of the County Györ-Moson-Sopron. The micro-region of Csorna holds most of the settlements of Hanság and Rábaköz together. In spite of the fact that the micro-region is situated in one of the most developed region of the country it was always considered as an inner periphery. For centuries especially in Rábaköz agriculture was the most important economic basis of the region. From the point of view of tourism important landscape conditions is characterized the area in a shadow-situation, the Rábaköz does not have outstanding attractions but it is situated between the Szigetköz/Danube and Lake Fertö recreational areas of national importance, in the vicinity of the Austrian boarder. The micro-region can be characterized by rural small settlement structure. The wetlands, swamps and forests of Hanság and the banks and gallery forests of river Rába are of great ecological value. The landscapes of Rábaköz and Hanság dispose of such natural and folksiness values which have disappeared from Western-Europe. If we are talking about the Hanság it is inevitable to mention it is past as well because the structure of the landscape changed dramatically due to the drainage efforts of the society. According to Fig. 1 still in the first part of the $19^{\text {th }}$ century the Hanság (the North-western part of the later micro-region area) was mostly a vast marshland. The drainage works of local scale started already in the $17^{\text {th }}$ century but the most intensive works were elaborated during the $18^{\text {th }}$ century when the main canals were built and Rábca, Kis-Rába was regulated. The most intensive and effective drainage works were elaborated in the second half of the $19^{\text {th }}$ century. With the drainage works vast areas of the former marshland were turned into grass fields (Takács and Pellinger, 2008). For information we have to turn to the historic maps as the KSH databases shows the rate of the different land use forms just since 1895. In the settlements of Hanság and Tóköz during the last century we witnessed an extremely drastic decrease of grasslands, moderate growth of plough lands and stronger expansion of forests. Unfortunately mostly forests were established just as poplar plantations during the socialist regime. 

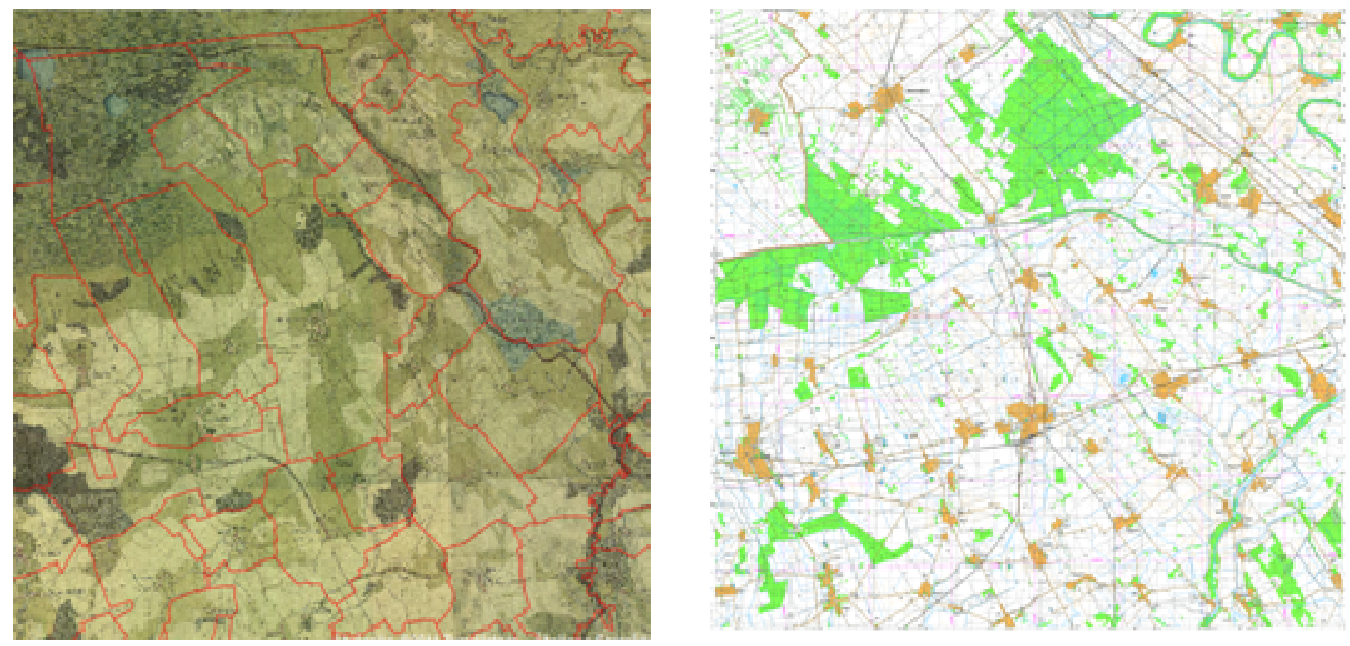

Figure 2. The area of Hanság-Rábaköz during the II. Military survey and nowadays (source: http://www.tajertektar.hu, RTA 50)

Because of the constant decrease of marshlands, wetlands and pastures, low lying areas of poor quality were turned into plough fields, nowadays about 5-10\% of the cultivated area is frequently waterlogged which means a financial loss for the farmers and in total loss in biodiversity as well. The historic maps show considerable land use changes in the micro-region (Fig. 2).

\section{Results}

\section{Habitat function}

Analyzing the habitat function, we used the data of the Fertö-Hanság National Park, and compared the share of protected areas and according to the importance and occurrence of protected species we evaluated the function. The share of protected areas in the region of Hanság and Tóköz is really high, here we can find areas of the National Park, National Ecologic Network, Natura 2000 areas, Ramsar sites and MAB biosphere reserve as well. According to Fig. 3 in the settlements of Hanság, Tóköz the National Park and Natura 2000 areas dominate meanwhile in Rábaköz the areas of National Ecologic Network are in majority. It is important for the farmers because while in the area of Natura 2000 different support schemes are available for farming in the area of National Ecologic Network there are no such support available.

The Natura 2000 area of Southern-Hanság and Tóköz (Lake of Barbacs and Fehértó) covers all the remained natural habitats, which preserve just the fraction of the former vast marshland but in spite of the extensive drainage several natural values of community importance can we find in Hanság. Among the habitats of community importance in greatest extension we can find mesotrophic meadows and Molinia meadows. Thanks to the habitat-reconstruction works of the National Park Directorate there are again great water surfaces in Hanság. The Nyirkai-Hany became in the last five years significant waterfowl station. The alder and ash swamp woodlands, riverine ash-alder woodlands and riverine oak-elm-ash woodlands are of great importance in Hanság.

The Natura 2000 areas of Rábaköz are characterized by forests and watercourses. Unfortunately because of the intensive cultivation the natural forests of the region were shrinked (http://www.fhnp.nemzetipark.gov.hu). 


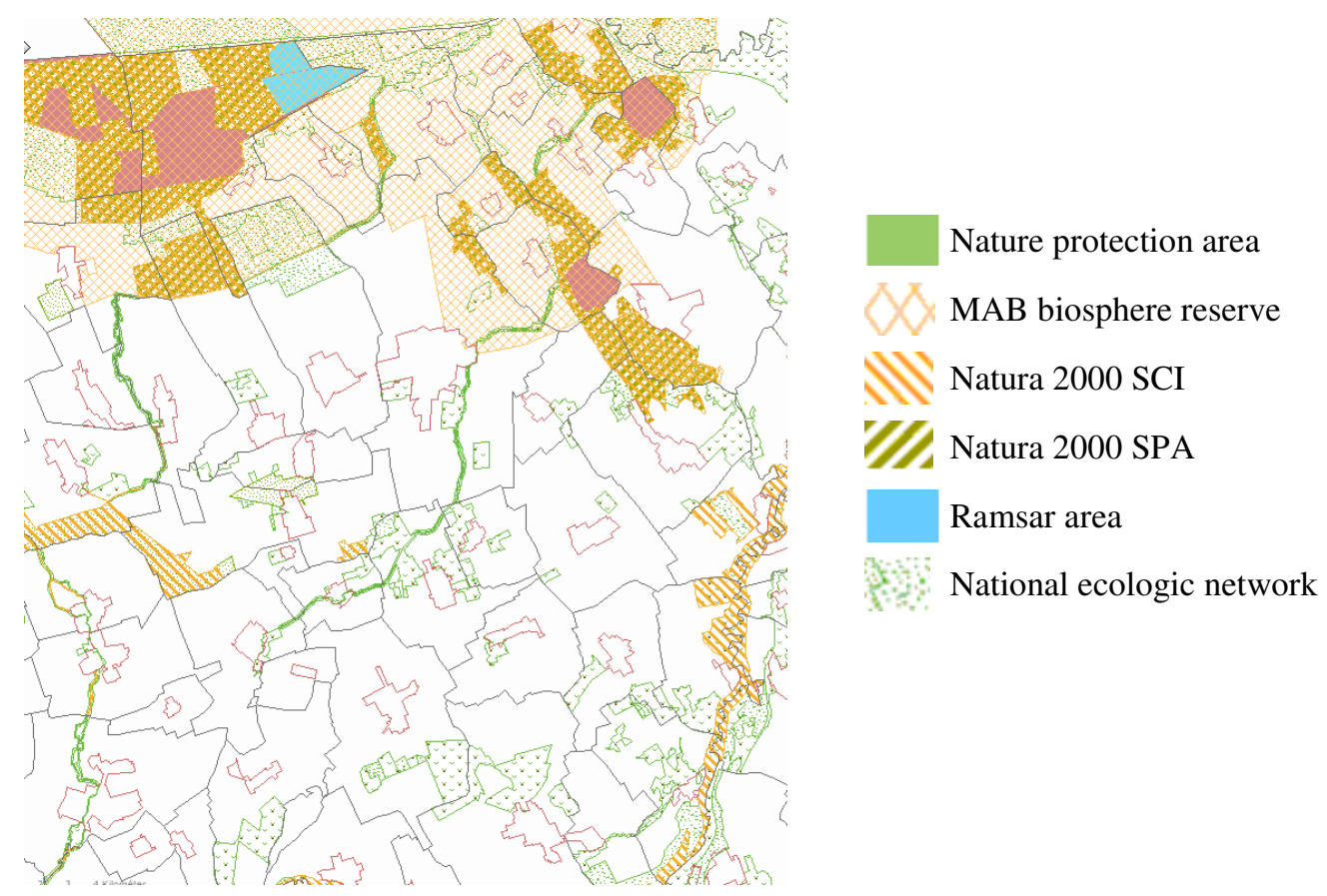

Figure 3. System of protection areas in the micro-region (source: TEIR, http://arcgis.vati.hu:81/teirgis_termeszetvedelem)

If we look at the share of protected areas in the settlements of Hanság-Tóköz we can find really high values as these are parts of the national park area: for example in Barbacs, Csorna the nature protection areas cover more than $30 \%$ of the administrative areas of the settlements. Natura 2000 areas cover also large parts of the villages of Hanság as well (Fehértó 42\%, Tárnokréti 56\%). The National Ecologic Network category means restrictions in different land use forms and building activities enforced by the Local Building Code (Fig. 4).

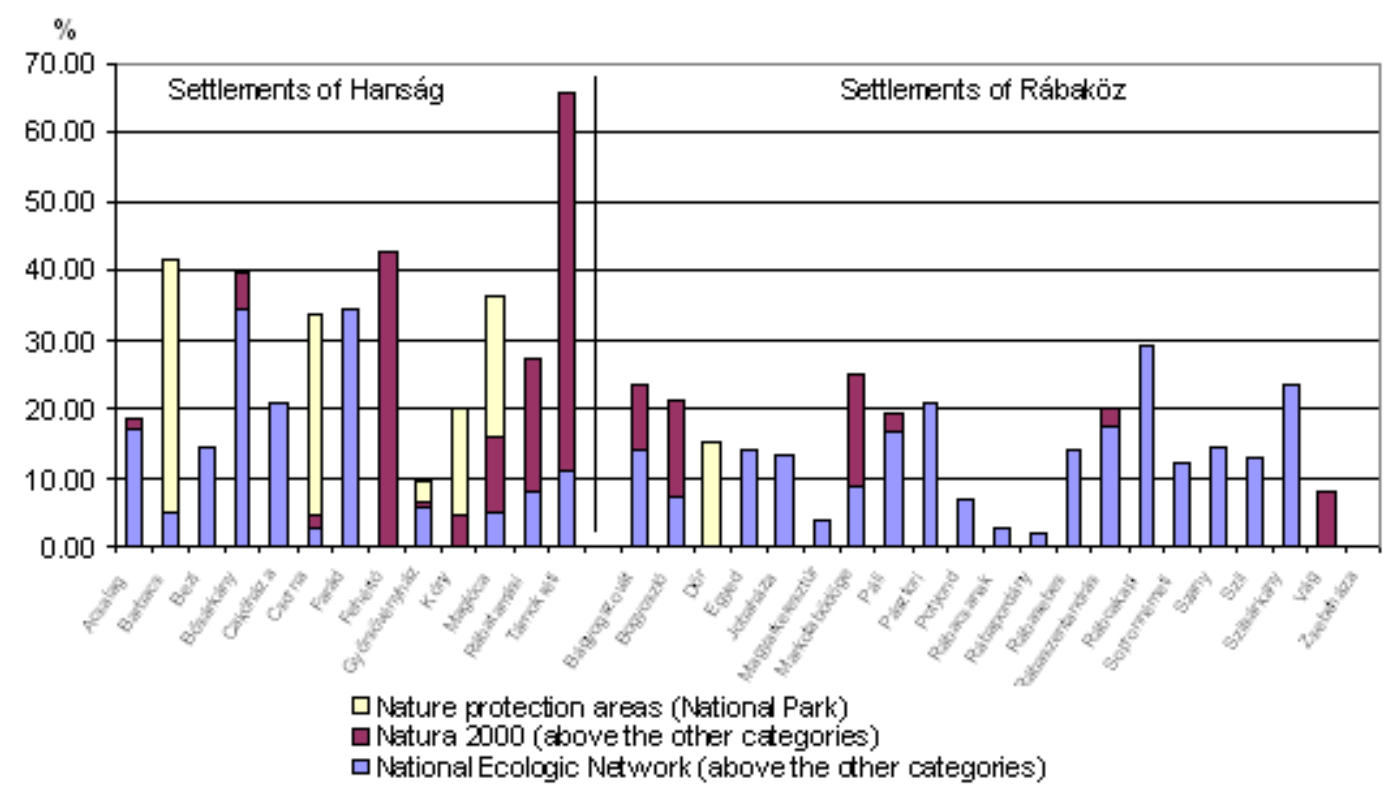

Figure 4. Ratio of protected areas per settlements in Hanság and Rábaköz (source: https://teir.vati.hu) 
Because of the high rate of protected areas (which means land use restrictions) and parallel to that the cultivated areas we considered it important to analyze the level of agri-environmental payments. The analysis revealed that in spite of the high rate of protected areas the agri-environmental payments are not extreme high with the exception of a few settlements (Fehértó, Maglóca), in case of some settlements even though high rate of the village is Natura 2000 area, the rate of agri-environmental payments is low. In Györsövényház even though the ratio of protected areas is low the ratio of agri-environmental payments are high. Farmers have to apply for agrienvironmental payments and because of the strict application rules and shortages of the financial frames just few farmers got real compensations for the environmental restrictions. The Natura 2000 areas are mostly pastures in Hanság and Rábaköz and the low profitability of husbandry hardens the state of the farmers (Fig. 5).

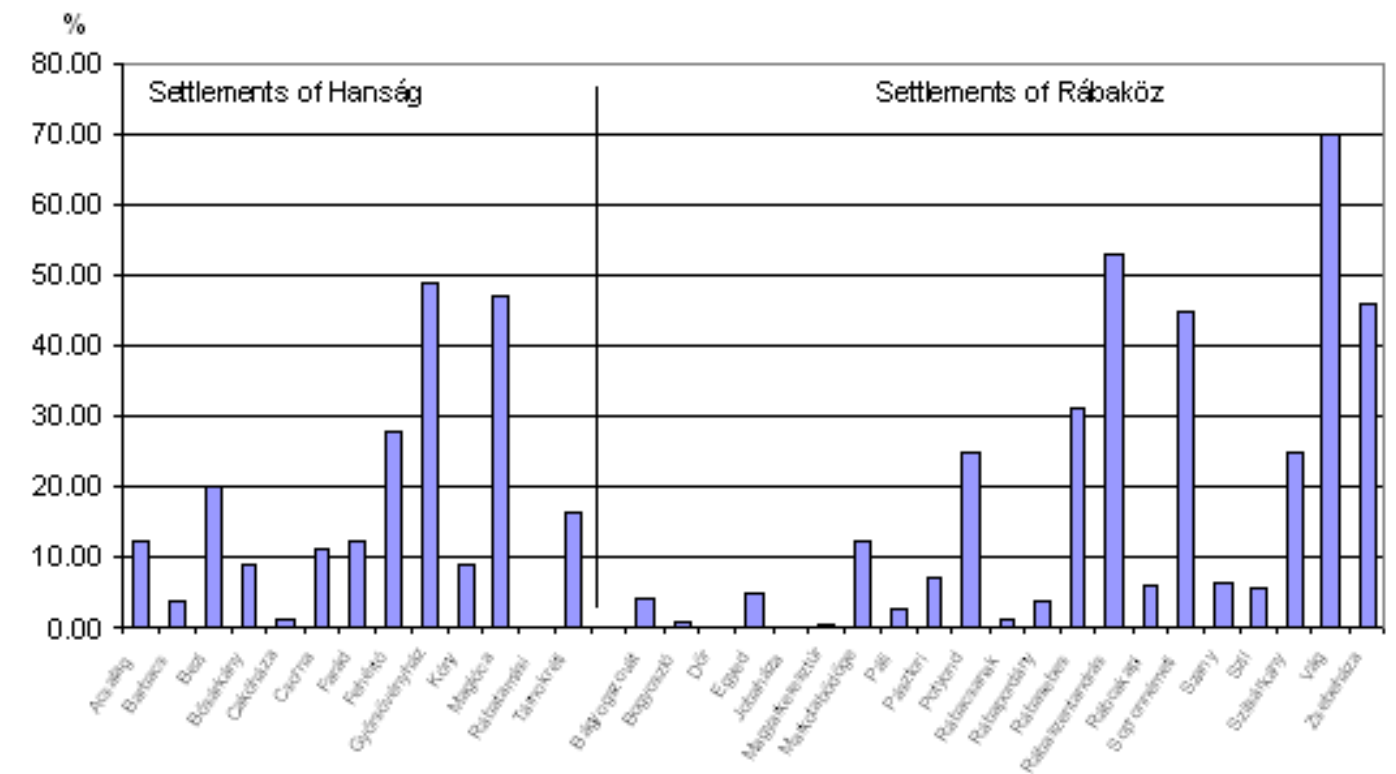

Figure 5. Ratio of agri-environmental payments in relation to direct payments (source: http://www.mvh.gov.hu)

\section{Information functions}

In the sphere of information functions we examined the cultural-educational function, recreational function and aesthetic function.

We analyzed the cultural-educational function of the landscape mainly through the unique landscape values using the on-line database of the recently finished TÉKA project (http://www.tajertektar.hu) and explored the exhibitions and study trails in the region. A special initiation of the Hungarian landscape protection is the listing of the unique landscape features. According to the Nature Conservation Act (Act No. LIII. of 1996. 6.§) the landscape element which has unique natural value, the man-made landscape elements which has special importance regarding to the nature, historical, cultural, scientific or aesthetic aspect and has special importance for the society can be considered as unique landscape values. Mainly it was the National parks directory's duty to list the unique landscape features. Because of the high portion of nature protection areas of these settlements the survey was mostly elaborated just for the built up areas, so about the $92 \%$ of the registered unique landscape features are cultural 
landscape elements in spite of the diversity of natural values (Fig. 6). We can observe in the region high density of sweep wells (Fig. 7) reflecting the former wide-spread land use forms of grazing (Kollányi, 2009).

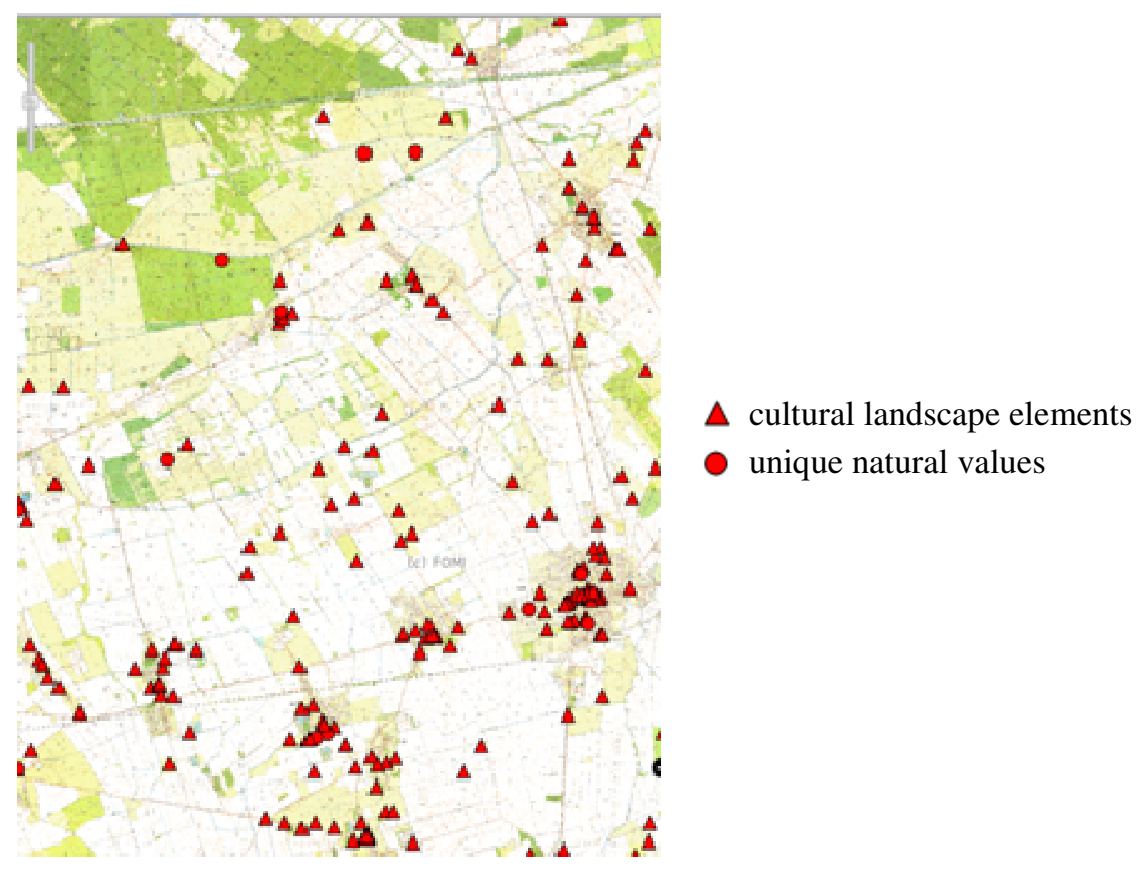

Figure 6. Unique landscape features in the micro-region of Csorna

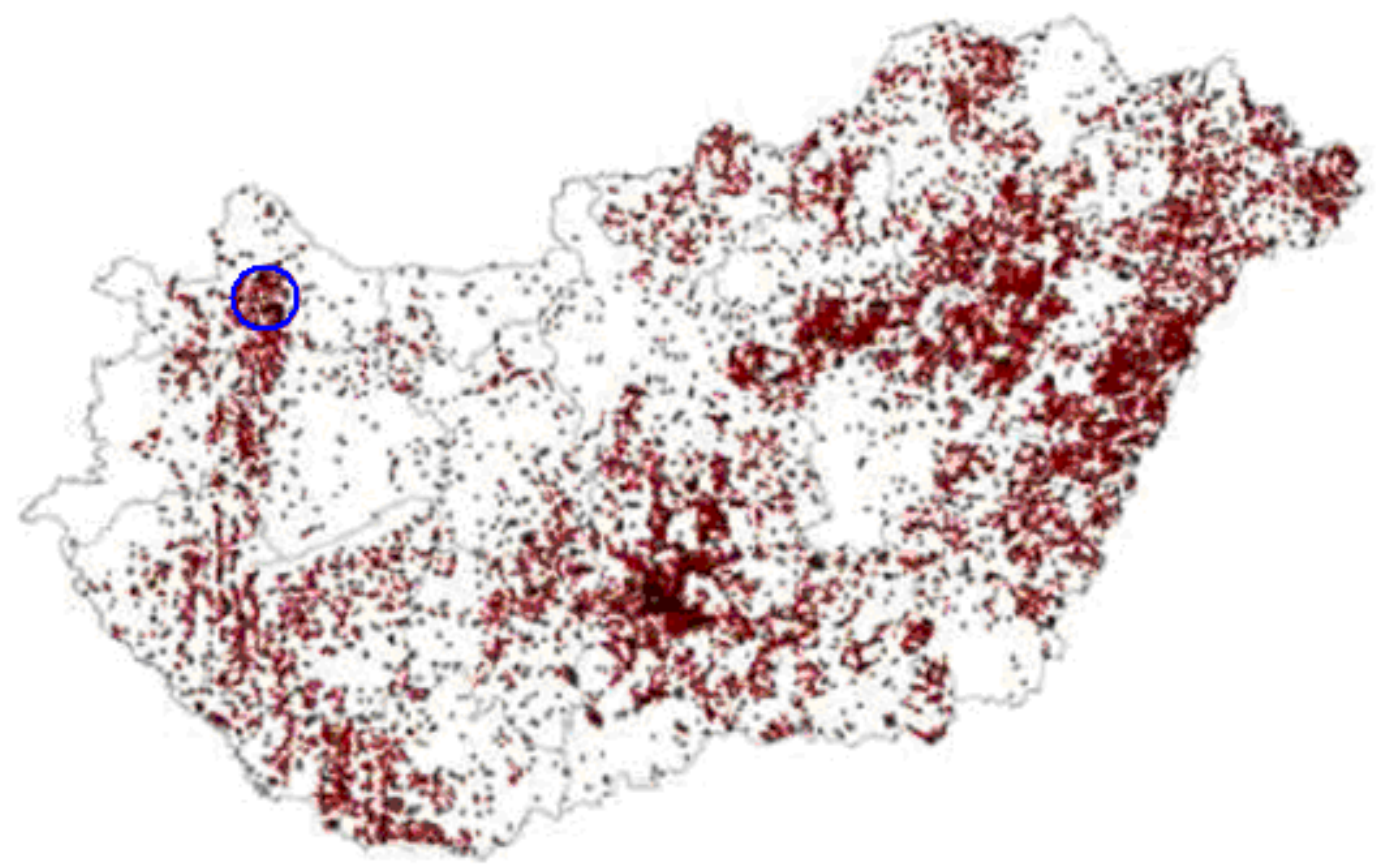

Figure 7. High density of sweep wells in Rábaköz (indicated with the blue circle) reflecting the traditional land use forms

In this part of the Fertö-Hanság National Park there is just one study trail, two look out towers and two exhibitions of smaller scale. The centre of the National Park 
Directorate is in the vicinity of Lake Fertö, all the programs are concentrated here, the Hanság can be considered rather periphery from this point of view. Also the vulnerability of the strictly protected areas prevents publicity. In Rábaköz we do not find study trails or exhibitions related to natural values at all.

To explore the recreational function of the analyzed landscapes we scanned the data about rural tourism and other recreational possibilities available in the region. Analyzing the capacity of rural tourism and other recreational possibilities the results are also disappointing: in Hanság and Tóköz just in Csorna, Bősárkány, Farád and Kóny can we find some guesthouses, in Rábaköz with the exception of the settlements along the river Rába we can not talk about rural tourism at all. If we look at other recreational activities related to natural endowments we can see just ceasing possibilities: the thermal bath of Csorna in spite of the great development plans of the self-government is not functioning any more (because of ownership conflicts) the former beaches of Rába are abandoned, etc. In 2009 we carried out a questionnaire survey to explore the opinions of the people living in several settlements of the micro-region. The interviewees evaluated the state of the micro-region from different point of view on a 10 point scale. According to the results of the survey, it became clear that great deficiency is the lack of social, cultural and active recreational possibilities. So it is important to use the means of landscape architecture as well for broadening the possibilities of recreation.

Analyzing the aesthetic function of the landscape we have to relay on the most subjective elements. We can distinguish four major landscape character types in the micro-region:

1. The remnants of the former marshland mostly characterized by wetlands, pastures, forests, mosaic landscape, low intensity cultivation. Mostly typical for the northern part of the micro-region and are part of the Fertö-Hanság National Park. Here can we find the remnants of the former magic world of Hanság with lakes and moors in the low lying areas, the regular system of canals, poplar forest plantations and alder forests, pastures with willows, etc.

2. Drained marshland mostly characterized by plow fields and pastures with low and medium intensity cultivations especially the settlements of the so called Tóköz. We can see mosaic-like landscape plow fields fragmented by forest belts and canals, mostly where we can find the last habitat rehabilitations such as the Nyirkai-Hany. The characteristic and remained landscape features bear aesthetic values of great importance. Here would be important to enhance the characteristic landscape elements of canals, wetlands (Konkoly-Gyúró, 2010).

3. Plain landscape with dominant plough land

a. Monotonous plain landscape with large plough fields.

b. Plain landscape with mosaic like cultivation with smaller plough fields, forest belts, pastures.

Rábaköz is mostly characterized medium and high intensity of cultivation with the remnants of pastures along the watercourses which mostly are Natura 2000 areas. In Rábaköz there are great areas characterized by monotonous plough fields.

4. Riverside landscape characterized by high rate of gallery forests with small pastures (because of its relatively narrow lane we have not distinguished it as individual landscape unit). 
Looking at aesthetics naturally the former marshlands and areas of low intensive cultivation and mosaic like landscape are of greater value. Especially in the area of Rábaköz is it important to break the monotony of the vast plough fields by forest belts, patches and pastures.

\section{Cultivation function}

Among the carrier functions we have analyzed the cultivation function by the ratio of cultivated areas. Especially the ratio of plough fields are extremely high in the microregion (national average 48\%, local 66\% with great local differences), in spite of the traditional predominance of grazing the ratio of the grass fields in the region is average nowadays (Fig. 8). The conversion of pastures into plough fields continued still in the last years as well which process is not appropriate with the natural conditions this is proved by the high share of waterlogged areas. According to the village administrator $10-20 \%$ of cultivated areas are waterlogged. The area of fruit and vegetable gardens is much less than the national average in spite of the considerable growth during the socialism and during the 1990s when the vegetable growing especially the cucumber which was called the "gold of Rábaköz" was significant.

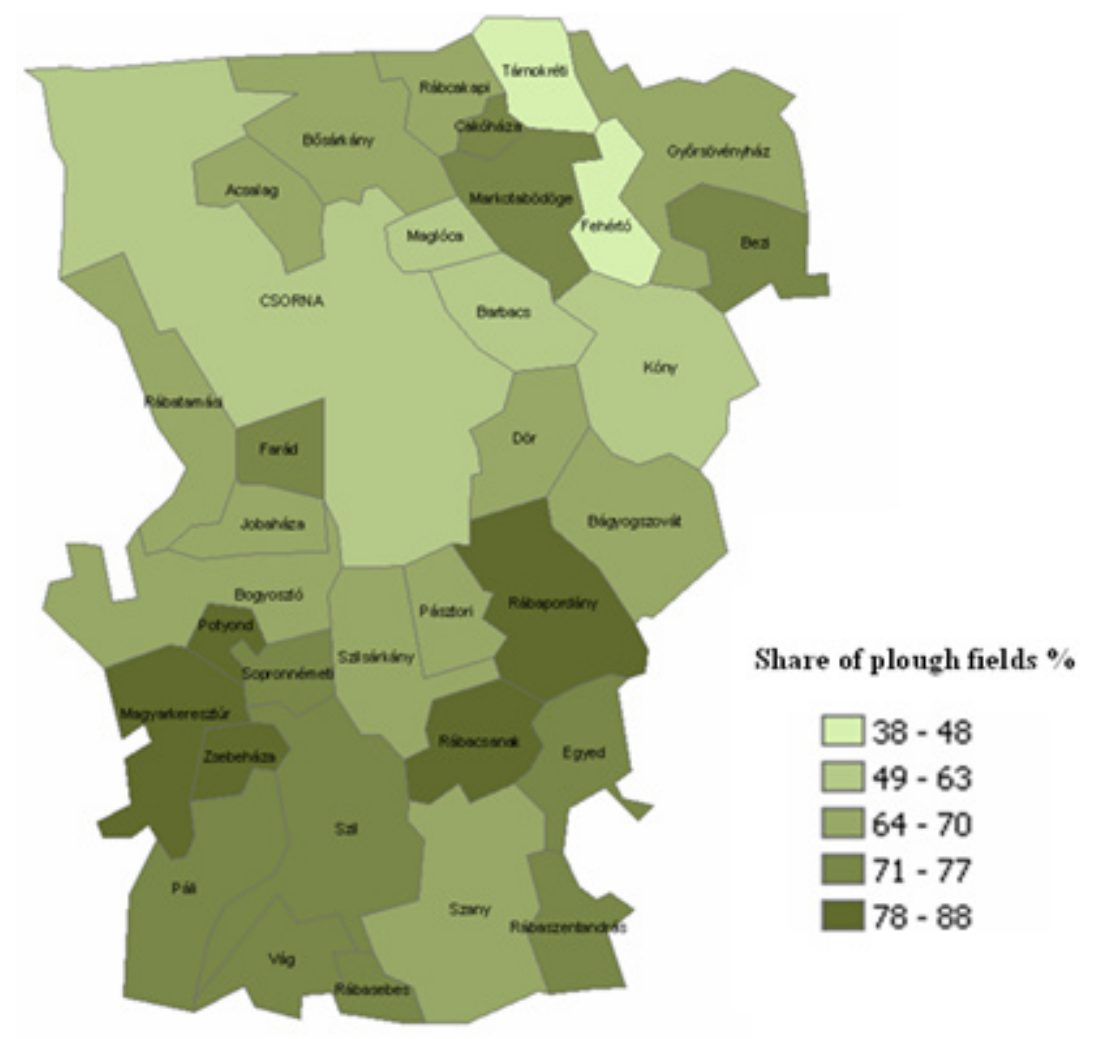

Figure 8. Share of plough fields in the micro-region (source: http://www.takarnet.hu)

\section{Discussion}

For a complex and effective rural development it is important to consider the landscape conditions and functions as well. Analyzing the landscape functions, next to different social and economic factors helps to support sustainable development of rural regions. Especially the agriculture and tourism are the main economic sectors which are 
affected by the natural and cultural endowments. To preserve the population of rural regions it is important to fulfil the various social needs as well (profitability, recreation, aesthetics, etc.). As the human society is also just a part of the nature maybe the most important constraints limits are the aspects of environmental sustainability.

Through indicators we analyzed the habitat, information and carrier functions of the landscape in both landscape units in the micro-region of Csorna and in both cases we revealed imbalances. The cobweb diagram (Fig. 9) shows the level of different landscape functions in the analyzed region.

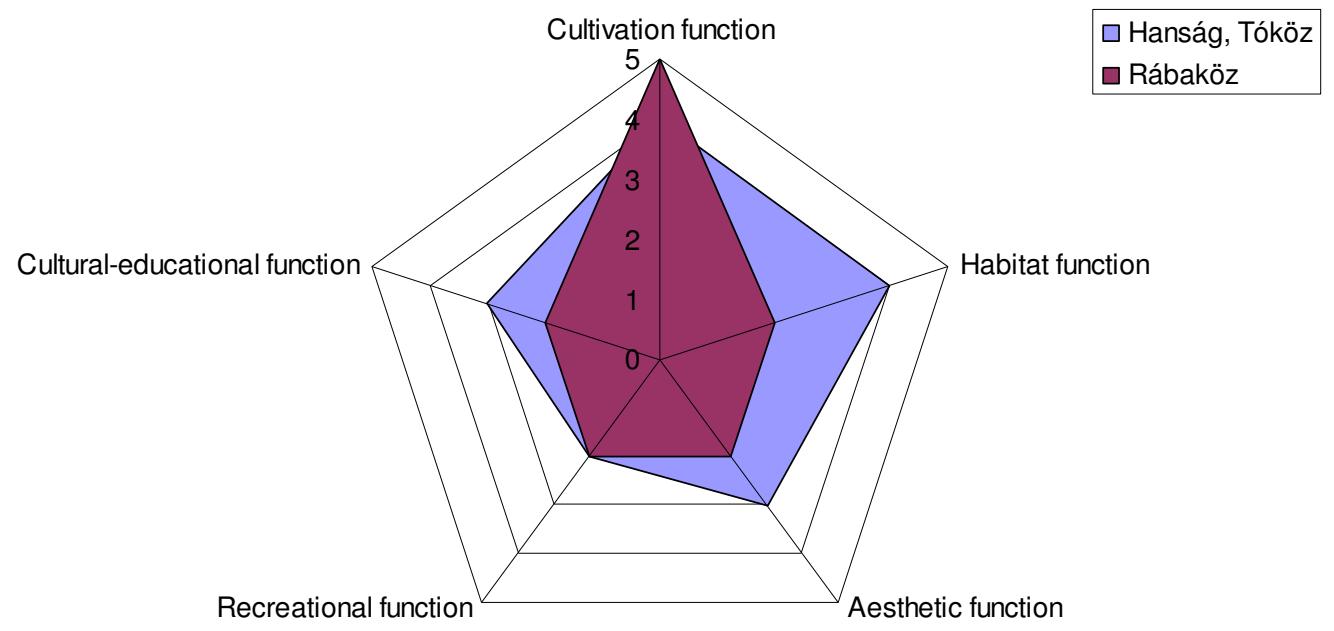

Figure 9. Level of landscape functions in the micro-region of Csorna

The micro-region is comprised of two major landscape units. One is Hanság and Tóköz which still preserved and bear the values of the former vast marshland and which landscape's majority is under nature protection (so the habitat function has got relatively high value). The analyzed indices have shown that for the region the natural values mostly mean land use restrictions and the population can not really enjoy the benefits (recreation, rural tourism, agri-environmental compensations) so the recreational services are inadequate, under average. In spite of the high rate of the nature protection areas the natural values do not appear as attractions even among the unique landscape values are not listed because of the nature protection status and there are just few possibilities (study trails, exhibitions) for publicity, so the level of culturaleducational services is inadequate. It would be important to list natural landscape values in the protected areas as well in spite of the current practice. The ratio of cultivated areas in spite of the high rate of protected areas is extremely high (in cobweb diagram the cultivation function above average). In order to avoid the damages of farmers because of the high rate of waterlogged areas it would be important to increase the share of pastures and forests in the low lying areas. Looking at the landscape aesthetics the protected areas are of high value but in the cultivated areas especially plough fields, the landscape is monotonous (so the aesthetic function got medium value in the cobweb diagram). So the planting of elements of mosaic like and the traditional landscape such as vegetation along canals, forest belts, trees and greater areas of pastures should be enhanced. The second part of the micro-regions is Rábaköz which can be characterized by high intensity of cultivation. Here the enhancement of ecologic values and services are important so the habitat and information (aesthetics, recreation, education) services are inadequate so these should be developed. In Hanság and along Rába the 
development of ecotourism has possibilities in Rábaköz the agro-tourism. The rural development strategies in the region should focus on adjusting the land use forms to the landscape conditions and fulfil the needs of the society.

Acknowledgements. We would like to thank Márton Kiss who provided valuable comments to the study and Rita Várszegi for her help in fulfilling the formal requirements. The research was co-financed by the TÁMOP-4.2.1/B-09/1/KMR-2010-0005 project.

\section{REFERENCES}

[1] Costanza, R., d'Arge, R., de Groot, R., Farber, S., Grasso, M., Hannon, B., Limburg, K., Naeem, S., O’Neill, R. V., Paruelo, J., Raskin, R. G., Sutton, P., van den Belt, M. (1997): The value of the world's ecosystem services and natural capital. - Nature 387: 253-260.

[2] EEC (1992): 2078/92 EU Tanácsi Rendelet a tájfenntartás és a környezetvédelem követelményeinek megfelelö mezőgazdasági termelés támogatásáról.

[3] Ghimessy, L. (1984): A tájpotenciál. Táj, víz, ember, energia. - Mezőgazdasági Kiadó, Budapest

[4] Glatz, F. (2010): Sikeres vidéki térségek. - MTA Történettudományi Intézet - MTA Társadalomkutató Központ, Budapest, 192 p.

[5] de Groot, R. (1992): Functions of Nature: Evaluation of Nature in Environmental Planning, Management and Decision Making. - Wolters-Noordhoff, Groningen, 315 p.

[6] de Groot R.S., Wilson M., Boumans R. (2002): A typology for the description, classification and valuation of Ecosystem Functions. - Goods Services Econ. 41(3): 393408.

[7] de Groot, R. (2006): Function-analysis and valuation as a tool to assess land use conflicts in planning for sustainable, multi-functional landscapes. - Landscape and Urban Planning 75: $175-186$.

[8] Kollányi, L. (2009): Tájértékek kataszterezésének metodikája. - Ormos Imre Tudományos Ülésszak, LOV 2009, Tájépítészeti tanulmányok, p. 159-165.

[9] Konkoly-Gyúró, É. (2010): Határon átívelő tájak karaktere, A Fertő-Haság medence és Sopron térsége. - Nyugat-Magyarországi Egyetem Kiadó, Lővérprint

[10] LEADER European Observatory (2001): Global competitiveness for rural areas. http://www.aeidl.be/publications/rural.php

[11] MEA (Millennium Ecosystem Assessment) (2005): Ecosystems and human well-being: Biodiversity synthesis. - World Resource Institue, Washington D.C., 86 p.

[12] Takács, G., Pellinger, A. (2006): Nyirkai-Hany vizes élőhelyrekonstrukció. http://www.ferto-hansag.hu/nyirkai-hany

[13] Török, K. (2009): A Föld ökológiai állapota és perspektívái (a Millennium Ecosystem Assessment alapján). - Magyar Tudomány 170(1): 48-53.

[14] Vejre, H., Abildtrup, J., Andersen, E., Andersen, P.S., Brandt, J., Busck, A., Dalgaard, T., Hasler, B., Huusom, H., Kristensen, L.S., Kristensen, S.P., Præstholm, S. (2007): Multifuncional agriculture and multifunctional landscapes - land use as an interface. - In: Mander, U., Wiggering, H., Helming, K. (eds): Multifunctional land use - meeting future demands for landscape goods and services. Springer, Berlin, Heidelberg (Germany) 